\title{
Note on geometric algebras and control problems with $\mathrm{SO}(3)$-symmetries
}

\author{
Jaroslav Hrdina ${ }^{1}$, Aleš Návrat ${ }^{1}$, Petr Vašík ${ }^{2}$, and Lenka Zalabova ${ }^{3}$ \\ ${ }^{1}$ Vysoke uceni technicke v Brne Fakulta strojniho inzenyrstvi \\ ${ }^{2}$ Vysoke uceni technicke $\mathrm{v}$ Brne \\ ${ }^{3}$ Masaryk University
}

December 8, 2021

\begin{abstract}
We study the role of symmetries in control systems by means of geometric algebra approach. We discuss two specific control problems on Carnot group of step 2 invariant with respect to the action of $\$ \mathrm{SO}(3)$. We understand geodesics as curves in suitable geometric algebras which allows us to asses an efficient algorithm for local control.

\section{Hosted file}

AGACSE_Hrdina.pdf available at https://authorea.com/users/450066/articles/548480-note-ongeometric-algebras-and-control-problems-with-so-3-symmetries
\end{abstract}

